\title{
Practitioner Response to Williams Paper
}

\begin{abstract}
Eugene A. Scanlan
is President of eScanlan Company; he founded this nonprofit management consulting firm in 2001 and has since worked with a number of local, regional, national, and international clients. Prior to founding his firm, he spent 18 years as Vice President and Senior Vice President of The Alford Group Inc., a national consulting firm. He has also served as a foundation program officer and fiscal manager at The Chicago Community Trust, the foundation officer for The Brookings Institution, the Director of Development for Defenders of Wildlife, and as an independent consultant to several organizations. Prior to his career in nonprofit consulting and development, he spent ten years as a college and university administrator and teacher. In addition to his consulting work, Gene holds several academic appointments, including serving as: Adjunct Associate Professor at the University of Maryland University College; Associate Professorial Lecturer in International Affairs, Elliott School of International Affairs, George Washington University; and as a member of the Advisory Council for the George Mason University Nonprofit Management Program. He also is a certified on-line instructor. He Chaired the Association of Fundraising Professionals' (AFP) Research Council, served on the Steering Committee for the Professional Advancement Division, and recently served a third term as a Board member of AFP's DC Chapter. He continues to serve on several AFP committees and task forces. He is a published author and a frequent presenter. $\mathrm{He}$ received the 2003 Professional Fundraiser of the Year award for the DC Chapter of AFP.
\end{abstract}

International Journal of Educational Advancement (2007) 7, 190-192.

doi:10.1057/palgrave.ijea.2150066

Ms. Roderick Williams' research focuses on three critical areas for both donors and organizations, and their importance to six categories of donors based on their ages. These areas are:

- Organizational outcomes: "the recent and/or long-term stated accomplishments of an organization."

- Organizational efficiency: "the percent of a charity's total spending for charitable programs, as opposed to overhead (fundraising and administrative costs)."

- Desire for information: "financial, outcome, or other information on a charitable organization that donors desire or actively seek when making a decision to give."

Her research highlights the baby boomer generation, which she defines in two categories as those 40-48 years old ("Baby boomer 1") and those 49-58 years old ("Baby boomer 2"). The Baby boomers, their attitudes towards the nonprofit sector, their capacity for giving, and their giving interests and volunteering have grabbed the attention of the charitable sector in recent years. Much media coverage and considerable ongoing research has centered on the transfer of wealth, now underway and expected to reach an estimated $\$ 41$ trillion or more over the next 50 years, as is pointed out by Ms. Williams. 
The Center on Wealth and Philanthropy at Boston College (www.bc. edu/research/cwp), and the Indiana University Center on Philanthropy (www.philanthropy.iupui.edu/), among others, are carrying out extensive longitudinal studies of both the Baby boomers and giving/volunteering by Americans.

Valuable specific research studies and results, such as those presented by Ms. Williams, are often overlooked by nonprofit organizations and fundraisers as they carry out their day-to-day work. And yet understanding the attitudes, needs, and motivations of all donors, regardless of their ages, should inform professionals at all levels in the sector if they and their organizations are to be successful. Examples of some recent and not-so-recent articles and studies include "Boomers on Track to Give 20 percent More to Charity than Average Donor, Fidelity Charitable Gift Fund survey reports" (www301.charitablegift.org/learn-aboutcharity/news/12-07-2006.shtml), and "Did You Know that 1 percent of Families Contribute 26 percent of Charitable Dollars?" (www.bc.edu/research/cwp/features/ didyouknow.html).

Ms. Williams clearly highlights the implications of her study's results for nonprofit organizations, fundraisers, and public policy. This author would add the following lessons, all drawn from his own experiences, that he believes are intrinsic to such research results and are for nonprofit organizations and especially for fundraisers:

- The best fundraising continues to be donor centric. Studies and results, such as those presented by Ms. Williams, can serve as guides to the thinking and attitudes of broad groupings of donors by such criteria as age, but should not be used to define the attitudes of each individual. There is usually a broad range of attitudes and beliefs within any survey group and it is incumbent upon the organization and the fundraiser to know each donor, to the fullest extent possible, as an individual. Sometimes, the "outliers" can be those with the most impact on an organization.

- Organizational outcomes, as Ms. Williams points out, are usually stated by the organization itself. While some organizations can present statistics on numbers served, dollars raised, performances attended, or other data, others may have a more difficult time showing what specific outcomes/accomplishments they have achieved. Some organizations see evaluation measures and benchmarking as only being a necessity when a funder requires them. Yet, donors increasingly want to see information about accomplishments and meaningful data that support these stated accomplishments. Ms. Williams points out that younger donors wanted this information more often than mature donors-and it is this group that will form the next wave of major givers after the baby boomers. The lesson for nonprofit organizations should be to develop more substantive ways to present real accomplishments, but also be prepared to tell "stories" that can make the numbers real.

- Organizational efficiency, especially in terms of the costs of administration and fundraising, or overhead, versus the costs of charitable programs run by the 
organization, is of growing concern to donors and policy makers. Organizations that raise considerable money may indicate that they have little or no fundraising costs on their 990 forms, while others may seek to assign fundraising and administrative costs to budget categories that conceal the actual uses of funds. Media coverage of nonprofit abuses and scandals frequently focus on excessive fundraising costs per dollar raised (especially when an outside fundraiser is used), or organizational leaders using dollars raised for personal benefit. While there are different views of what is an appropriate ratio of administrative and fundraising costs to program costs, it is imperative that organizations practice openness and transparency in all of their financial reporting, including allocating costs to budget centers that reflect the real nature of the expenditures. There can be legitimate reasons for high fundraising and/or administrative costs, and, if this is the case, nonprofit organizations should share the legitimate reasons for these with anyone asking for this information.

- Ms. Williams points out that different age groups may seek information from different types of sources, such as the internet, emails, published materials, or through other means. The clear lesson here is that organizations should utilize a full range of resources to make their information available to the public. Many organizations are now asking how each interested person would like to receive information from the organization, what types of information they would like to see, and how frequently they want to receive it. This enables the individual to tailor the type of information, its amount and frequency, and how it is transmitted, to his or her particular preferences.

- Organizations also need to not only share their accomplishments with supporters but also openly share their problems. When sharing problems, however, the organization should also be prepared to present its action plan or solution for the problems-and how individuals can help make these happen. Of course, an organization with a continual flow of problems-a "we're sinking again" approach-may effectively turn away many people. But openness and honesty will be appreciated.

- Finally, all of the above points really have an underlying theme for any organization: the best organizations are those that create an atmosphere of honesty, openness, transparency, and concern for the individual, all of which are based on a strong ethical foundation and compliance with regulations and public policy. 